\title{
Decentralization: Proliferation of Territories in Musi Rawas Regency, Indonesia
}

\author{
Zaman Zaini $^{1}$, Ahmad Hidayat ${ }^{2}$ \\ 1,2Institut Ilmu Sosial dan Manajemen STIAMI, Faculty of Public Administration, Let. Jend. Suprapto Road, DKI Jakarta 10530, Indonesia
}

\begin{abstract}
Formation of new autonomous regions are meant to promote effective governance, by reducing the span of control of the previous more extensive area, improving the quality of public services, increasing the wealth of the local people, setting the fiscal balance between central and local government, increasing employment and capital inflow. However, the formation process of North Musi Rawas as a new autonomous region took 11 years since proposed in 2002 until signed by the central government in 2013. This paper argues that the factors behind the long delay were mainly political factors, instead of administrative. Administrate, the region is eligible to be established as a new autonomous region. This study uses the NVivo Program as a tool for conducting primary and secondary data analyzed from direct interviews, meeting results and statements from related parties. From the research results obtained that the political process, however, involves a series of events in its history that generated constraints for establishing North Musi Rawas as a new autonomous region. The historical facts include leadership contest between Governor of South Sumatera and Regent of Musi Rawas, conflict over control of the natural gas resource in Suban 4, central government's moratorium policy to new autonomous region formation, leadership change, and internal conflict within the social movement to demand autonomy among local people. It argued in this paper that absence of political network and lack of organization of social mobility to demand freedom allows the recurring events that created constraints to the political process of establishing North Musi Rawas as a new regency. The absence of political network to elites in the regional and national levels complicate the political communication to pursue autonomy. It explains why the conflict between Governor and Regent can halt the proposal. Weak organization of social movement allowed internal strife and complicated the resource mobilization to achieve the political goal.
\end{abstract}

Keywords: Political, Conflict, New Autonomous Region, and Power

\section{Introduction}

The regional division is a process of dividing an existing administrative region into two or more new autonomous areas based on the Law of the Republic of Indonesia No. 32/2004 on Regional Government resulting from the amendment to the Law of the Republic of Indonesia No. 22/1999. The cornerstone of its implementation based on Government Regulation No. 78/2006. While spatial conflict is the potential for territorial disputes arising from the existence of a boundary line dividing one region into two different areas.

The principle of decentralization and regional autonomy and regional expansion in Indonesia as an archipelago of tropical countries have its characteristics regarding large numbers of unevenly distributed populations, socio-cultural diversity, natural resources, flora and fauna as well as the physical diversity of the region. Based on this variety, in geographical perspective, Indonesia has the potential for high regional conflict [1].

Expansion of the territory into several parts of the new region is an effort to improve the quality and intensity of service to the community. Regarding regional development, candidates for new areas that will be in form need to have a resource base that must balance between one another. It needs to do in order not to happen disparity that striking in the future [2]. Furthermore, in an effort to expand the region will be created a new public space which is a collective need of all citizens of the new territory. The new general area will affect the activities of people or society. There are those who feel in favor or vice versa in obtaining services from the new government center in the cause of the movement distance change [3]
The process of regional division has realized indeed causing conflict between various community groups and involving local elites either vertically or horizontally. Several cases of domestic elite political disputes in the process of formation of new areas occurred between local elites of Bangka Belitung and South Sumatra based on their mine disincentives divided into provinces and other districts on the mainland of South Sumatra and regional sentiments [4].

This paper focuses on the prolonged political conflict that causes the delay of the establishment of North Musi Rawas District of South Sumatra Province 2007-2013. The previous political strife caused by the lack of harmony between Rawas elite and Musi Rawas Ridwan Mukti due to defeat of Rawas figure in elections (Pemilu kepala daerah) Regent Musi Rawas 2005 which later developed into personal conflict between South Sumatra Governor Alex Noerdin with Regent Musi Rawas Ridwan Mukti in conflict issue of Suban 4 Gas Wells in 2008-2013. The battle between the two main actors of South Sumatera Province culminated in the election of the Governor of South Sumatra in 2013 where both compete for the support of Golongan Karya Party (Golkar). Due to the power struggle between the two figures, the process of forming the North Musi Rawas Regency which has been fought by the people of North Musi Rawas since 1962 has delayed again.

Based on the above explanation can be identified some of the problems that became the focus of analysis of this writing, especially to the issue of why the expansion of the region of Musi Rawas Regency becomes delayed, whereas all administrative and technical requirements have met. In connection with the development of the area, what caused the political conflict during the formation of North Musi 


\section{International Journal of Science and Research (IJSR) \\ ISSN (Online): 2319-7064}

Index Copernicus Value (2016): 79.57 | Impact Factor (2015): 6.391

Rawas Regency. This paper will answer the main problem creating the process of expansion of the region of North Musi Rawas Regency delayed and caused the occurrence of political violence.

\section{Literature Review}

The concept of decentralization often regarded as a formulation and a problem containing an absolute value to solve the issues of the relationship between the central government and the regions. It is because decentralized governance systems viewed as a way or system that can restore power at the bottom of a social network. Thus, decentralization as a system of government implies the democratization of politics. Nevertheless, the definition of devolution itself still debated, both conceptually, the policy and its implementation in the administration. The debate about the meaning of decentralization is not only limited to its terminology but also in the sense of decentralization itself [5]-[7].

Decentralization is one way that can be done to divide the power (the division of power). Theoretical distribution of power can go through two methods, namely the capital division of power and the area of a section of power. Capital division of power is a division of control according to the trial-political doctrine of [8], namely dividing energy into power to enforce laws (executive power), ability to make rules (legislative power) and judicial power (judicative power). While the area of division of energy can do in two ways, namely decentralization, and deco-centration. Devolution is a legal (legal based) handover of power to carry out specific functions or functions left to local authorities formally recognized by the constitution [9].

Another view of the definition of decentralization is expressed by [6]. According to it devolution "is the transferor delegating of planning, the decision making or management authority from the central government and its agencies to field organizations, subordinate units of government, semi-autonomous public corporations, area or regional authorities, functional authorities, or nongovernmental organizations." The type of decentralization determined by the extent to which authority or power transferred from the center and institutional arrangement or what institutional agreements are used to move it. In this case, decentralization can be the simplest of delivering routine tasks of government to devolution to perform specific functions previously held by the central government.

According to [10], further decentralization can be carried out in two ways, namely by performing functional decentralization or by carrying out devolution of the territory. Functional decentralization is a transfer of authority from the central government to specific institutions that have defined functions as well. For example, is the transfer of power or authority to administer a toll road from the Department of Public Works to a company or a state entity. Meanwhile, territorial decentralization is the transfer of power from the central government to public institutions operating within certain area boundaries, such as delegation of certain powers from the central government to provincial, regency or municipal governments. By both ways, according to [11], four forms of decentralization can be used by parties to transfer authority, both in the planning and execution of the body, namely deco-centration, delegation, devolution, privatization. In decentralization, local units are formed with specific powers they possess and the power to perform particular functions by which they can carry out their own decisions, initiatives and administrations themselves [9]. The definition of decentralization according to [9], contains two elements which, namely the establishment of autonomous regions and the handover of powers legally to deal with specific areas of government.

According to [6], decentralization gives birth to both financial and legal (regarding self-governing, decisionmaking) of local government units. With devolution, activities are previously undertaken by the central government substantially left to local government units and thus are beyond the control of the central government. Moreover, [6] says that the main characteristics of decentralization are: Firstly, the presence of local, autonomous, independent local government units perceived as separate levels of government with which the authority is given to him with little or no direct control from the central government. Secondly, local governments have clear geographical boundaries in which they exercise influence and provide public services. Third, the provincial government has status as a corporation and has the power to manage the resources needed to carry out its functions.

Meanwhile, according to [12], decentralization will give birth to local government, while deco-centration will give birth to local government (local state government or field administration). According to [12], decentralization has various features such as the transfer of authority to perform satisfied management functions from the central government to the autonomous regions; the tasks submitted may be specified or are residual functions; the recipient of body is an autonomous region; the transfer of authority shall mean the authority to establish and implement the policy, the power to regulate and administer a local interest; the authority to regulate is the authority to develop generally accepted norms of law, or of an abstract nature; authority to manage is the authority to set legal standards that are individual or concrete; the existence of an autonomous region is outside the hierarchy of the central government organization; shows the pattern of inter-organizational power relations; and creating political variety and diversity of structure in the political system [13].

In order to run the decentralized system of government, in the regions formed local government which is a separate legal entity of the central government [13]. To these local governments, a portion of the government functions (formerly a central government function) to be implemented by the local government. In addition to the regions are also submitted sources of income that can be used to finance the functions that have been submitted. Similarly, the organization is formed by Dewan Perwakilan Rakyat Daerah (DPRD) whose members are elected through an electoral system.

Thus, the local government is an institution which has autonomous powers to determine its policies, how to execute

\section{Volume 6 Issue 12, December 2017}




\section{International Journal of Science and Research (IJSR) \\ ISSN (Online): 2319-7064}

Index Copernicus Value (2016): 79.57 | Impact Factor (2015): 6.391

those procedures, and how to finance them. Implementation of decentralization can then see in various aspects of the existing local government system, such as financial aspects, aspects of authority delegation, personal aspects, as well as attitudes and behavior of elites at the central and regional levels.

\section{Method}

\subsection{The Phenomenological Approach}

This approach aims to describe a phenomenon as it is lived and experienced, the "lived experience," from the person involved. It understood that the description is subjective. The approach aims to explore not what is, but what is perceived to be [14]. The objective is not to answer or solve, but to gain a deeper understanding. The individual descriptions examined for commonalities or themes and differences. There is no attempt to establish cause and effect but rather to find "what it is that renders this or that experience its special significance" [15].

Phenomenological research requires the researchers to engage in "bracketing" throughout the data collection and analysis. Previous assumptions and knowledge are put aside to allow the researcher to observe without preconception (Shackle). For this reason, it recommended that the literature review conducted after data collection and analysis. We completed a cursory literature review for the research proposal and a thorough search after data collection. The sample kept deliberately small because a great deal of data generated and "qualitative analysis is an exceedingly laborious and time-consuming enterprise" [16]

\subsection{Study Design}

This research uses descriptive qualitative research method. According to [17], qualitative research conducted because researchers want to explore explanatory non-quantifiable phenomena such as the process of a work step, the formula of a prescription, the notions of a diverse concept, the characteristics of a good and a service, a picture, styles, the procedures of a culture, the physical model of an artifact and so forth. The positivistic paradigm more or still influences the graphics format, so this form is dominant using the phenomenological standard. Instruments in this research are observation, interview, and documentation. In this study needed human as a researcher because humans can adjust according to environmental circumstances.

\subsection{Sample and Setting}

The sample in this study consists of the opposing parties, in this case, the individuals that support and not support the expansion of the region. Then another example is a neutral party that is an academic or central government that is not directly related to the development of the area that occurred.

\subsection{Data Collection and Analysis}

Primary data in this study is the opinion or information provided by informants or respondents who directly or indirectly provide information related events and phenomena that occur. Data processed in this research can come from the results of meetings, seminars, and public interviews or associated writings.

From the primary data in the form of text conversations then using the program NVivo to facilitate thematic analysis in this study. To research with NVivo, you create a project to hold the information, data, observations, ideas and most importantly the connections between them relevant to your research task [18].

\section{Result and Discussion}

NVivo is a software commonly used for qualitative research. Usually, qualitative research aims for exploration and understanding of data in more depth [19]. The qualitative data are in-depth and detailed, so it is also lengthy. As a result, qualitative data analysis is specific, especially to summarize data and integrate it into a logical flow that is easily understood by others [20]. The nature of this data differs from quantitative information that is relatively more systematic, standardized, and quickly presented in a concise format. From the primary or secondary data obtained using the NVivo Program received as follows:

Table 1. Pearson Correlation Coefficient

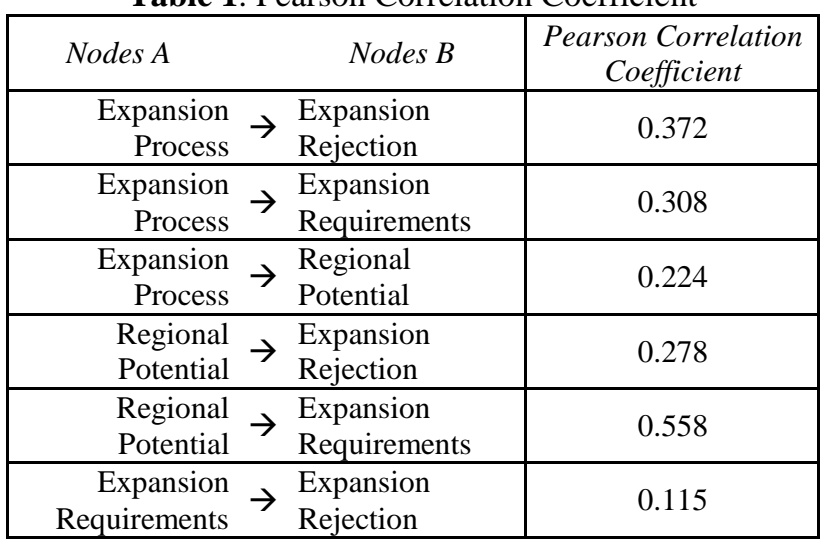

A Nodes is the container in NVivo for categories and coding. Nodes can represent any types - concepts, people, abstract ideas, places and any other things that matter to your project. Nodes can be kept without organization as Free Nodes, or organized hierarchically, if you wish, in Trees [18].

Table 1 shows that the most substantial relationship exists in the potential of the region as a condition of the proliferation of territories. In this research becomes the most influential aspect of other aspects that become the requirement of a division of a region.

The expansion of the region in principle aims to improve the welfare of the community, by enhancing and accelerating services, democratic life, regional economy, potential regional management, security and order, and harmonious relations between regions and centers. In essence proliferation of territories as an effort to increase resources on an ongoing basis, Increasing harmony of development between parts and between sectors. Strengthening national integration which overall can improve the quality of life by Government Regulation No. 129 / 2000.

\section{Volume 6 Issue 12, December 2017}




\section{International Journal of Science and Research (IJSR) \\ ISSN (Online): 2319-7064}

Index Copernicus Value (2016): 79.57 | Impact Factor (2015): 6.391

In the essence of regional expansion objectives as an effort to increase sustainable resources, enhance harmony and development among sectors, strengthen national integration. To achieve that goal all, need to increase the quality of apparatus resources in all fields because the role of human resources is expected to improve the performance of the organization in providing excellent service to the community and support in regional development in the region. Rational resource development strategy that is done consistently and continuously through the process of accumulation and utilization of human capital has been proven to have a strategic role for efforts to improve the welfare of the broader community. This explains the importance of the implementation and enforcement of human resource-oriented human resource management strategies at the organizational level to contribute to the improvement of the nation's competitiveness on an ongoing basis by Law No. 32/2004 which regulates the requirements of regional expansion.

According to [21], that the political phenomenon or the power of collective factors such as race, social differences and things that are socio-cultural. Elements that are common causes of the problem are class differences, racial views, and conflicts between horizontal groups. And parallel disputes between groups often arise in the form of ideological, political battles.

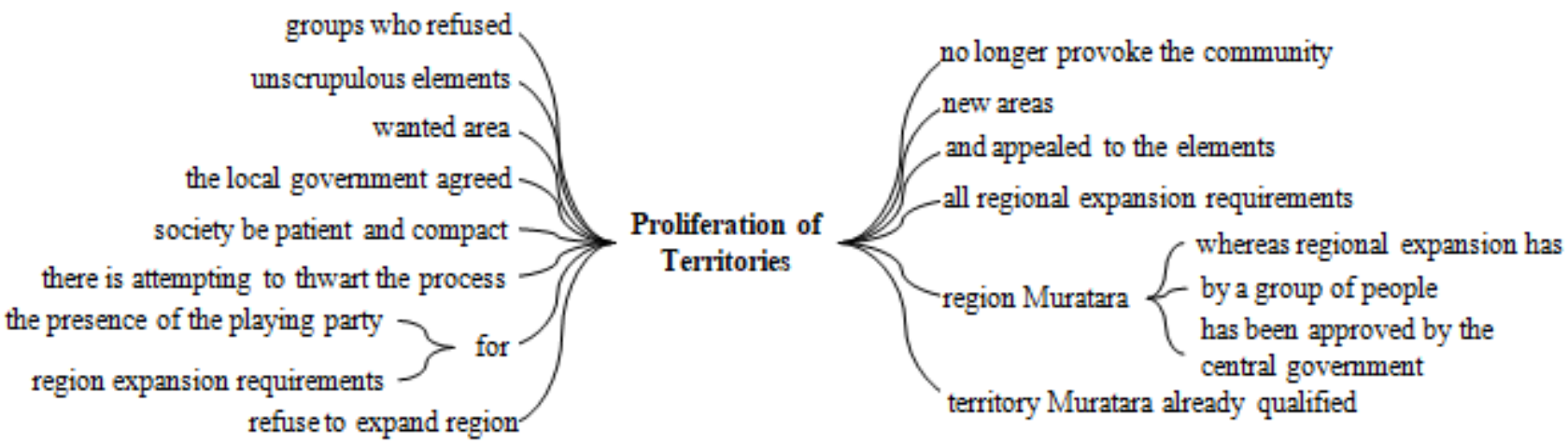

Figure 1: Result Review - Text Search Query

Figure 1 is the result of the NVivo Program linked to the search for regional expansion according to the theme of the study. The existence of conflicts that occur in the process of proliferation of territories is one aspect that needs further explanation.

Political conflicts in the process of establishing districts in accordance with four postulates which indicate the inevitability of political disputes are submitted [22], namely as follows: First, every society is subject to the process of change, and social change is everywhere; Second, every organization shows conflict and conflict; Third, every element in society contributes to disintegration and change; fourth, every culture characterized by the mastery of a small number of people against a large number of others.

Conflict is a social phenomenon that is always present in every society in every period of time. The battle is an integral part of social life because it is one of the products of social relations. The community consists of a large number of social relationships, so there is always a conflict between the citizens involved in social relations. Conflict arises because of limited resources and position. The resources needed for life are limited, as are the limited contested political positions. The view [23], concerns the issue of competition in the distribution of power which can lead to the political opposition because of the limited source of energy.

In addition to conflict, the consensus is also a social phenomenon that is always present in social relationships. The battle is always accompanied by agreement (compromise) because of the people's desire to resolve the dissent. In a democratic country, the role of understanding is essential in deciding conflicts so that conflicts will not undermine the solidarity of the community.

In connection with the demands of regional expansion, the conflict can identify in the form of resistance or rebellion against the parent region. Resistance caused by the lag and gap between the expectations and potentials of an area. According to [24], the theory of relative deprivation, the result of a rapid social change, disorganized social structures, population explosions and environmental imbalances can lead to accumulation of tension, frustration, insecurity and in turn lead to a very depressed feeling tend to explode in the form of violence and chaos.

According to [25], the occurrence of Relative deprivation caused by an imbalance between value expectation and value capabilities. Value expectations occurs because of the living conditions of people who expect their rights to be met. While the meaning of value capabilities is the condition of the people, who believe that they can achieve what hoped. In general, relative deprivation occurs when everyone has a number of expectations and demands on certain things they should have, but they have no ability to achieve what they expect. Thus, it can be said that they perceive a discrepancy between hope on the one hand and the ability to reach his expectations on the other.

\subsection{Personal Conflict Between the Governor and the Regent}

Several factors cause the personal conflict between South Sumatra Governor Alex Noerdin and the Regent of Musi Rawas Ridwan Mukti causing delays in the formation of Musi Rawas Regency: first, the conquest of Suban Gas Wells 4. and secondly, the contestation factor in the election of 


\section{International Journal of Science and Research (IJSR) \\ ISSN (Online): 2319-7064}

Index Copernicus Value (2016): 79.57 | Impact Factor (2015): 6.391

Governor of South Sumatera 2013. Political conflicts the two political actors started when the seizure of Suban 4 Subur Gas region between Musi Banyuasin Regency with Musi Rawas Regency. Due to the political conflict, the process of establishment of North Musi Rawas Regency in Dewan Perwakilan Rakyat (DPR) to delayed.

These delays result in political impacts such as changes in the government's policy on the mechanisms for the establishment of new autonomous regions and the occurrence of demonstrations, violence and political violence at the local level.

The entry of Suban 4 gas well into the territory of the Musi Rawas Regency 2007 caused the community and the figure of Musi Banyuasin for the second time to be disappointed with Alex Noerdin when he was the Regent of Musi Banyuasin (1998-2008). Society Musi Banyuasin assesses Alex Noerdin not have the ability to keep its territory from dispute Suban 4 with Musi Rawas Regency. Previously, Musi Banyuasin community was disappointed with Alex Noerdin when Musi Banyuasin Regency split into two regions, namely Musi Banyuasin Regency and Banyuasin Regency in 2002. To cure Musi Banyuasin community's disappointment towards him, he tried to recapture Suban 4 which has been handed over by Central Government to Musi Regency Rawas through Regulation of the Minister of Home Affairs No. 63/2007.

Alex Noerdin's efforts realized after he was elected Governor of South Sumatra 2008. The problem of Suban 4 which has had a permanent legal power was again sued by the government of Musi Banyuasin Regency on the instigation of South Sumatra Governor Alex Noerdin. Alex Noerdin's attitude to restore his reputation that fell in the eyes of Musi Banyuasin society when viewed from the psychological aspects of Sigmund Freud and Harold Lasswell called Megalomaniac. The urge to re-raise the case of Suban 4 into the legal domain because it was motivated by Alex Noerdin's guilty conscience to the Musi Banyuasin community in the fact of Suban 4 with Musi Rawas Regency. To restore his authority that degraded over the defeat against the Regent of Musi Rawas Ridwan Mukti then he tried to raise the case of Suban 4 again.

Steps to speed up the settlement of the problem of the subgas well 4 Governor Alex Noerdin sent a letter to the Minister of Home Affairs No.136 / 2188 / I / 2009 dated July 16, 2009 on the Musi Rawas District Boundary with Musi Banyuasin with copies to 11 relevant officials, including to the regional head of Musi Rawas own.

The reasons put forward by South Sumatera Provincial Government were responded by the Regent of Musi Rawas Ridwan Mukti strongly and took the attitude as a form of alignment of Governor Alex Noerdin and defended the interests of the Government of Musi Banyuasin Regency. This action is a violation of the law and unlawful acts by the ruler or the ruling party. This alignment is considered to be a severe violation of rights and authority in good governance because it is clear that the Suban area is within the jurisdiction of Musi Rawas Regency.
Furthermore, to resolve conflicts between Musi Rawas District and Musi Banyuasin Regency, the General Directorate General of MoHA followed up the Governor's Letter No. 136/2188/2009 by issuing the official letter number 136/4090/2009 addressed to the Regent of Musi Banyuasin and Musi Regent Rawas, South Sumatera Governor and Dewan Perwakilan Rakyat Daerah (DPRD) leaders of each district to hold a finalization meeting on the boundary of Musi Rawas Regency with Musi Banyuasin Regency on Thursday, November 26, 2009. In the meeting was seen contestation between South Sumatra Governor Alex Noerdin with Regent Musi Rawas Ridwan Mukti where Alex Noerdin has forced his will by forcing Ridwan Mukti to approve the proposal of the Governor of South Sumatra on the withdrawal of the New Border Line of both Musi Rawas Regency and Musi Banyuasin Regency.

In the discussion on the border issue, the Regent of Musi Rawas Ridwan Mukti said that the attitude of the Governor of South Sumatra Alex Noerdin is unfair, subjective, biased or in favor of Musi Banyuasin Regency. The position of Governor Alex Noerdin is considered not as Governor of South Sumatra but has acted as if the Governor of Musi Banyuasin. Therefore, the Regent of Musi Rawas Ridwan Mukti expressly refused to approve the proposal/recommendation about the finalization of the Governor of South Sumatra and immediately leave the meeting referred to unconstitutional impose the will and violate the law.

Regent Musi Rawas Ridwan Mukti still insists that the problem of Suban 4 is final and binding. Conflicts of border issues between Musi Rawas Regency and Musi Banyuasin Regency have been completed and have legal basis such as, firstly, the Minister of Domestic Affairs No. 63/2007 has been published in Article 1 explicitly stated by Musi Rawas Regency as a natural gas resource producing region earth from Suban 4 well located in the region of Musi Rawas Regency. Second, based on Map Year 1926 Location Well Suban 4 is located in the area of Musi Rawas Regency. Third, the location of Suban 4 well located in Pauh Village, RawasIlir District, Musi Rawas Regency. Fourth, people living around Suban 4 wells have ID card of Musi Rawas Regency. Fifth, based on the landowner's information dated March 27, 2007, the area that is currently the location of Suban 4 wells originated from his land and had since entered into the territory of Musi Rawas Regency. Sixthly, since the issuance of Regulation of the Minister of Home Affairs No 63/2007-2009, the DBE of the Suban 4 well has been transferred to the Government of Musi Rawas Regency. Seventh, there has never been any objection from the Government of Musi Banyuasin Regency regarding such position and condition, including to the Minister of Home Affairs Regulation No. 63/2007.

The Governor's letter No. 136/2188 / I / 2009 dated July 16, 2009 , on the issue of Suban 4 resulted in the strengthening of personal conflicts between South Sumatra Governor Alex Noerdin and Musi Rawas Ridwan Mukti. This particular battle occurred in the process of proliferation of territories North Musi Rawas Regency which had been proposed and already discussed in Dewan Perwakilan Rakyat (DPR) to be disturbed. To address the position of the Governor against

Volume 6 Issue 12, December 2017 


\section{International Journal of Science and Research (IJSR) \\ ISSN (Online): 2319-7064}

Index Copernicus Value (2016): 79.57 | Impact Factor (2015): 6.391

the conflict of Suban 4, Regent Musi Rawas Ridwan Mukti sent a letter Number: 140/768/I/2009 which is very important to the Head of RawasIlir, Village Head as an area directly adjacent to Musi Banyuasin Regency. In the letter, the Regent of Musi Rawas asked the district to secure it further. As the front guard in the implementation of government policy in the field, it is expected to the Head of District, Village Head to be able to give full and comprehensive information to the community about the border issue between Musi Rawas Regency and Musi Banyuasin Regency. The attitude of the Regent Ridwan Mukti proves that the people of Musi Rawas are ready to defend their territory to the last drop of blood.

People at the border, especially the residents of Hamlet Five Village Beringin Makmur two firmly support the Regent Ridwan Mukti. They reasoned that all government administration affairs such as the making of identity cards, Family Card, Farmer Group Assistance and their political rights in the general election through the Village Government of Beringin Makmur Two RawasIlir District Musi Rawas Regency and never dealt with the Government of Musi Banyuasin Regency. They objected to the efforts of the Government of Musi Banyuasin who had transferred the Boundary Stake between Musi Rawas Regency and Musi Banyuasin Regency which has been deep into the Dusun Five Village of Beringin Makmur Two.

Amid the restlessness of the people on the border, the Minister of Home Affairs sent a telegram to the Governor of South Sumatra, the Regent of Musi Rawas Regency and Musi Banyuasin Regency and the Chairman of the Dewan Perwakilan Rakyat Daerah (DPRD) of Musi Rawas Regency and Musi Banyuasin Regency to attend the final meeting of the district boundary of Musi Banyuasin Regency and Musi Rawas Regency number : 136/4090/SJ dated November 19, 2009, held on November 26, 2009, at the Ministry of Home Affairs.

The prolonged conflict between Alex Noerdin and Ridwan Mukti in the Suban 4 gas disputes dispute ultimately affected the two actors in the nomination to become Governor of South Sumatera 2013. As incumbent Alex Noerdin tried to maintain his position as Governor of South Sumatra, although his reputation declined after his defeat in the elected Governor of DKI Jakarta 2012. Ridwan Mukti after winning the elections in 2005 Musi Rawas Regency is considered a young figure and new star of the Golongan Karya Party and is expected to be a strong candidate to replace Alex Noerdin as Governor of South Sumatra in 2013.

\subsection{Implications for the Proliferation of Territories}

The high enthusiasm of the Rawas community to realize the North Musi Rawas Regency began to have a negative implication after the government issued a moratorium policy (postponement) after 2007. The implementation of autonomy based on Government Regulation No. 129/2000 did not match as expected. This plan was adopted after the government evaluated the application of new autonomous regions, whose results were primarily inadequate to meet targets and expectations. The autonomous district has failed to improve welfare, accelerating economic growth which is the primary objective of a newly independent region by the central government.

The government expects the House of Representatives (Dewan Perwakilan Rakyat) to postpone the proposals for the regions to be expanded because the government is still reviewing the management and pattern of new autonomous regions. The Government considers that after ten years of evaluation (1999-2009) shows the results of the multiplicity of areas failed.

Responding to the incessant area proposed the formation of new regions and the government's firm stance to implement the moratorium policy, the People's Legislative Assembly (Dewan Perwakilan Rakyat) remains with its position which continues to process and proposes autonomous regions to the government. Submission of regional division is a territorial constitutional right to manage the area in accelerating the achievement of the welfare of the community.

The personal conflict between Alex Noerdin and Ridwan Mukti can resolve after the Suban 4 area is returned to Musi Banyuasin Regency to facilitate the expansion of North Musi Rawas Regency. Returns based on agreement between Muspida to two disputing districts. During a working visit to Rupit Sub-district on March 2, 2013, Governor Alex Noerdin firmly stated that he would take over the division of North Musi Rawas District and try his best to help the region. The attitude of Governor Alex Noerdin is to provide new spirit and hope for Rawas community will be the establishment of North Musi Rawas Regency. Although many think that the meeting is a political nuance to attract the sympathy of Rawas community ahead of the elections of the Governor of South Sumatra in 2013.

Although the border issue resolved by the Ministry of Home Affairs, the group supported the division and did not want the release of Suban 4 gas well to Musi Banyuasin Regency to refuse the agreement facilitated by Governor Alex Noerdin. The group that rejected the entry of Suban 4 to Musi Banyuasin Regency which came from RawasIlir community firmly dismissed the boundary already approved by the Ministry of Home Affairs.

The statement was apparently addressed to Ridwan Mukti as Alex Noerdin's political opponent during this time. But some people doubt Alex Noerdin attitude to accelerate the proliferation of territories North Musi Rawas District. There is a specific intent to change the position of Alex Noerdin, especially before the election of the Governor of South Sumatera 2013. One month after South Sumatra Governor Alex Noerdin political violence occurred on 29 April 2013, where residents again blocked the Sumatera Highway Km 72 in Muara Rupit. As a result of this blocking access, Lintas Sumatera Road became paralyzed. Vehicles from both directions cannot pass because the masses block the road by using wood that lined on the way. The closing action of Sumatera Highway access done due to public dissatisfaction with the process of proliferation of territories Muratara is unclear and always delayed.

On the occurrence of clashes of citizens with security forces that occurred in Sumatera Highway Muara Rupit causing

\section{Volume 6 Issue 12, December 2017}




\section{International Journal of Science and Research (IJSR) \\ ISSN (Online): 2319-7064}

Index Copernicus Value (2016): 79.57 | Impact Factor (2015): 6.391

casualties and injuries, South Sumatra Governor Alex Noerdin regretted the incident and did not have to happen. The process of proliferation of territories of North Musi Rawas Regency has reached the final stage, only need to refine and complete the boundary map. Muratara boundary map with Musi Rawas, Musi Banyuasin, and Bengkulu Province has been completed and stay with Jambi Province unfinished and planned in early March 2013 Ministry of Home Affairs will facilitate between South Sumatera Province with Jambi Province and between Muratara with Sorolangun Regency.

The implications of the conflict mentioned above are concluded that the settlement (consensus) conducted by South Sumatra Governor Alex Noerdin to return the gas well Suban 4 to Musi Banyuasin Regency as the basis for the process of establishment of North Musi Rawas Regency is an attempt to impose the reputation of Regent Musi Rawas Ridwan Mukti in the eyes of the North Musi Rawas community are intended to smooth itself in the process of nominating again in the elections of the Governor of South Sumatra 2013. This process is by the proposed by [26], [27] as political decay because many political factors cause the delay, the author uses the term Political Delay to explaining the political phenomenon that resulted in the delayed establishment of North Musi Rawas Regency.

\section{Conclusion}

The issuance of Regulation of the Minister of Home Affairs No. 63/2007 concerning the determination of Musi Rawas Regency as a producing area of Suban 4 gas wells is the primary cause of political conflict in the process of forming North Musi Rawas Regency. This political battle was the beginning of a political dispute between Alex Noerdin who at the time of the establishment of Suban 4 gas well was the Regent of Musi Banyuasin for 2 (two) periods (1998-2008) with Regent Musi Rawas Ridwan Mukti. The political conflict developed after Alex Noerdin was elected Governor of South Sumatra (2008-2013). With his authority as governor, he encouraged the government of Musi Banyuasin Regency to sue the Minister of Home Affairs Regulation No. $63 / 2007$. The grounds of the lawsuit are due to the clearance permits, land acquisition and financial administration carried out by the Government of Musi Banyuasin Regency. The lawsuit was rejected by the Government of Musi Rawas Regency by conveying facts based on juridical aspect, historical aspect, and sociological aspect. The political conflict between the two main actors of South Sumatera Province caused the process of the formation of North Musi Rawas Regency to delay due to the element of revenge of South Sumatra Governor Alex Noerdin to the Regent of North Musi Rawas Ridwan Mukti in the case of Suban 4.

The element of revenge is already in harmony with Megalomaniac theories of [28]-[30]. Megalomania can we interpret as a form of excessive obsession with itself because it feels the most powerful, the most powerful, and the greatest. Although megalomania does not rule out the possibility of suffering by people who are far from power, the figure of a leader refers to trends ranging from nonrelativity to losing the highest office in a group (state or company) to how to maintain that main position priority.
Behavior is only self-serving means already deviate far from the ideals of the beginning that has set, so the goal is not achieved and dormant in the middle of the road. This accident is because of leadership held by the wrong person, someone who is more concerned with the glory, greatness and personal wealth than the common goal that has mandated.

\section{References}

[1] T. Firman, "Decentralization reform and localgovernment proliferation in indonesia: Towards a fragmentation of regional development," Rev. Urban Reg. Dev. Stud., vol. 21, no. 2-3, pp. 143-157, 2009.

[2] B. Smith, "The origins of regional autonomy in Indonesia: Experts and the marketing of political interests," J. East Asian Stud., vol. 8, no. 2, pp. 211234, 2008.

[3] T. Firman, "Territorial splits (pemekarandaerah) in decentralising Indonesia, 2000-2012: Local Development Drivers or Hindrance?," Sp. Polity, vol. 17, no. 2, pp. 180-196, 2013.

[4] Sakai, Minako., "Resisting the mainland: the formation of the province of the Bangka-Belitung (Babel)," in Autonomy and Disintegration in Indonesia, Routledge Curzon, 2003.

[5] Davey, Kenneth., "Decentralization in CEE Countries: Obstacles and opportunities," Mastering Decent. Public Adm. Reforms CEE. Budapest LGI, 2002.

[6] Rondinelli, Dennis A., Nellis, John R., and G. S. Cheema, "Decentralization in developing countries," 1983.

[7] Mawhood, Philip., "Decentralization: The concept and the practice," Local Gov. third world, pp. 1-22, 1983.

[8] Baron de Montesquieu, Charles de Secondat. and Richter, Melvyn., The Politcal Theory of Montesquieu. CUP Archive, 1977.

[9] Maddick, Henry., Democracy, decentralisation and development. New York: Asia Publishing House, 1963.

[10] G. S. Cheema and D. A. Rondinelli, Decentralization and development: policy implementation in developing countries. Sage Publications, 1983.

[11] G. S. Cheema and D. A. Rondinelli, "Decentralization and development," Beverly Hills Sage Publ., 1983.

[12]D. A. Rondinelli, "Decentralizing public services in developing countries: issues and opportunities," J. Soc. Polit. Econ. Stud., vol. 14, no. 1, p. 77, 1989.

[13]B. Hoessein, "Tantangan Global danTanggapLokal: DesentralisasiDemokrasidanEfisiensi," Manaj. Pembang., vol. 19, 1997.

[14] Oiler, Carolyn., "The phenomenological approach in nursing research.," Nurs. Res., vol. 31, no. 3, pp. 178$181,1982$.

[15] Van Manen, Max., Researching lived experience: Human science for an action sensitive pedagogy. Routledge, 2016.

[16] Polit, Denise F. and C. T. Beck, "Generalization in quantitative and qualitative research: Myths and strategies," Int. J. Nurs. Stud., vol. 47, no. 11, pp. 14511458, 2010.

[17] Creswell, John W., Research Design: Qualitative, Quantitative, and Mixed Method Approaches, 4th ed. Thousand Oaks, California: SAGE Publications, Inc.,

\section{Volume 6 Issue 12, December 2017}




\section{International Journal of Science and Research (IJSR) \\ ISSN (Online): 2319-7064}

Index Copernicus Value (2016): 79.57 | Impact Factor (2015): 6.391

2014.

[18] Richards, Lyn., Using NVivo in Qualitative Research. Thousand Oaks, California: SAGE Publications, 1999.

[19] Bandur, Agustinus., "PenelitianKualitatif: Metodologi, Desain, \& Teknik Analisis Data Dengan NVIVO 10," Jakarta: MitraWacana Media, 2014.

[20]P. Bazeley and L. Richards, The NVivo Qualitative Project Book. Thousand Oaks, California: SAGE Publications, 2000.

[21] M. Duverger, The study of politics. Springer Science \& Business Media, 2012.

[22] Dahrendorf, Ralf., The modern social conflict: An essay on the politics of liberty. Univ of California Press, 1988.

[23] Laswell, Harold D., "Politics: who gets what, when, how," Clevel. Meridian Books, vol. 1958, p. 455, 1936.

[24] Walker, Iain. and H. J. Smith, Relative deprivation: Specification, development, and integration. Cambridge University Press, 2002.

[25] Gurr, Ted Robert., Handbook of political conflict: Theory and research. Free Press New York, 1980.

[26] F. Fukuyama, "What is governance?," Governance, vol. 26, no. 3, pp. 347-368, 2013.

[27] S. P. Huntington, Political order in changing societies. Yale University Press, 2006.

[28] Lasswell, Harold Dwight., Political writings. Glencoe, Ill., Free P, 1951.

[29]Freud, Sigmund., Civilization and its discontents. Broadview Press, 2015.

[30] Lasswell, Harold Dwight., The policy orientation of political science. Agra: Lakshmi Narain Agarwal, 1971.

Volume 6 Issue 12, December 2017

www.ijsr.net

Licensed Under Creative Commons Attribution CC BY 